ISSN 0258-7122

Bangladesh J. Agril. Res. 35(1) : 11-16, March 2010

\title{
EFFICACY OF MAHAPANCHA GAVYA (MPG) IN CONTROLLING DAMPING-OFF IN TOMATO CAUSED BY Pythium aphanidermatum
}

\author{
RAKESH KUMAR ${ }^{1}$, INDRA HOODA ${ }^{2}$ AND S.S. KARWASRA ${ }^{3}$
}

\begin{abstract}
Maha Pancha Gavya (MPG), a concoction made from five cow products was tested for its toxicity against Pythium aphanidermatum (Edson) Fitz. and its antagonists at $5,10,25$, and $50 \%$ concentration in in vitro to find out if it can be used in integration for the control of damping-off in tomato in nursery beds. MPG was very effective inihibiting the growth of $P$. aphanidermatum. At the highest concentration, the growth of the pathogen was negligible. Isolates of Trichoderma viride, T harzianum, and T. virens were also sensitive to MPG at all the concentrations. Their radial growth decreased, but it was fluffy in nature and sporulated profusely. MPG was not toxic against two bacterial antagonists i.e., Bacillus subtilis and Pseudomonas fluorescens. Soil application of $10 \%$ MPG to nursery beds improved seedling stand and gave upto $48.27 \%$ tlisease control, which was more than that given by individual antagonists. However, MPG improved disease control efficacy of all the antagonists when it was used in combination with them. Integrated treatment with MPG and B. subtilis gave maximum disease control (65.33\%). MPG enhanced seedling growth and it was more in combination with $T$. viride and $B$. subtilis. MPG in integration with neem cake and neem leaf extract gave complete control of damping-off and maxium increase in height of the tomato seedlings.
\end{abstract}

Keywords : Maha Panch Gavya (MPG), Trichoderma, Pythium aphanidermatum, integrated control, neem products, tomato, damping-off.

\section{Introduction}

There are evidences that the activities of soil borne pathogens and their antagonists are markedly influenced by the presence of various plant and animal products present in soil. These products not only change the physiochemical characteristics of the soil and improve the plant health but also increase the inoculum density of antagonists by serving as substrate media for their growth (Neelamagam and Govindarajalu, 2002; Chatmpawat and Sharma, 2003). This increase in inoculum density helps in overall reduction in disease. Contrary to these reports, some other workers have reported that urine and feaces of animals like cow, buffalo, sheep, and goat, etc. inhibit the growth of soil borne fungi (Raja and Kurucheve, 1998, 1999; Purushothaman et al., 2003). Even in $17^{\text {th }}$ and $18^{\text {th }}$ centuries, numerous abnoxious concentrations made of cow dung and urine were used for the treatment of canker disease of apple (Austen, 1657). Reddy and

${ }^{1}$ Ph.D. Student, ${ }^{2 \& 3}$ Senior Scientist, Department of Plant Pathology, CCS Haryana Agricultural University, Hisar-125 001, India. 
Padmodaya (1996) reported Maha Pancha Gavya (MPG) an organic formulation made from five cow products to be highly effective in controlling wilt of tomato. In integration with neem cake, it was better than carbendazim in controlling the disease and in increasing the plant vigour. Jahagirdhar et al. (2001) reported MPG to be effective in suppressing panama disease of banana caused by Fusarium oxysporum f. sp. cubense. Sugha (2005) found MPG to be toxic to five soil borne fungi in in vitro and effective in reducing damping-off of cauliflower seedlings caused by $R$. solani. Therefore, in the present study an effort was made to develop effective strategies for the management of damping-off of tomato caused by $P$. aphanidermatum with MPG in integration with biocontrol agents and neem products in nursery beds.

\section{Materials and Method}

The pathogen $P$. aphanidermatum was isolated from diseased tomato seedlings on Potato Dextrose Agar (PDA) medium. Antagonists of pathogen which included 7 isolates of Trichoderma spp. (T. viride-I, $T$ viride-II, $T$ viride-III, $T$ viride-IV, T. harzianum-I, T harzianum-II, and $T$ virens), Bacillus subtilis and Pseudomonas fluroscence were obtaied from the culture collection of the Department of Plant Pathology, CCS Haryana Agricultural University, Hisar. Tomato CV. S-7 was used as the host plant. Maha Pancha Gavya (MPG) was prepared by mixing $20 \mathrm{ml}$ of cow ghee, $50 \mathrm{ml}$ each of cow milk and curd, $480 \mathrm{ml}$ of cow urine, $400 \mathrm{~g}$ of cow dung, $20 \mathrm{~g}$ common salt and $10 \mathrm{~g}$ Baker's yeast. All the ingredients were put in closed plastic bucket, thoroughly stirred with wooden stick and allowed to ferment for 15 days with twice stirring daily. Then the fermented concoction was filtered through muslin cloth and its total volume was made to 1 litre. This was 100\% MPG and kept for use.

In vitro tests: $M P G$ was evaluated in in vitro for its toxicity against $P$. aphanidermatum and its antagonists by poisoned food technique given by Grover and Moore (1962). MPG was incorporated into PDA before sterilization to obtain $5,10,20$, and 50\% concentration and poured into sterilized Petri plates in triplicate. After solidification of the medium, the plates were inoculated with $5 \mathrm{~mm}$ mycelial discs of pathogen and antagonists taken from the periphery of 5 days old actively growing cultures. Each treatment had three replications and suitable controls were maintained simultaneously. Inoculated plates were incubated at $28 \pm 1^{\circ} \mathrm{C}$ for 3-7 days and linear growth of various fungi was measured. Percent inhibition of mycelial growth was calculated on the basis of growth in control treatments.

In case of bacterial antagonists, 2 days old cultures were just streaked on PDA impregnated with different concentrations of MPG. Observations on bacterial growth were taken visually and the growth was categorized as $--=\mathrm{Nil}$ 
growth, $+=$ scanty growth, $++=$ moderate growth, $+++=$ profuse growth, ++ $++=$ highly profuse growth.

Table 1. Effect of Maha Pancha Gavya (MPG) on the mycelial growth of Pythium aphanidermatum and its antagonists in culture at different concentrations.

\begin{tabular}{|c|c|c|c|c|}
\hline \multirow{2}{*}{ Treatment } & \multicolumn{4}{|c|}{ Percent inhibition at } \\
\hline & $5 \%$ & $10 \%$ & $25 \%$ & $50 \%$ \\
\hline T. viride-I & 5.56 & 57.78 & 88.89 & 88.89 \\
\hline T.. viride-ll & 0.0 & 0.0 & 61.11 & 72.22 \\
\hline T..viride-III & 5.56 & 11.11 & 38.88 & 72.22 \\
\hline$T$.. viride-IV & 22.22 & 72.22 & 88.89 & 100.00 \\
\hline T. harzianum-I & 0.00 & 11.11 & 44.44 & 72.22 \\
\hline T. harzianum-11 & 0.00 & 38.88 & 72.22 & 88.9 \\
\hline T. virens & 27.78 & 44.99 & 55.56 & 88.33 \\
\hline P. aphanidermatum & 5.56 & 16.66 & 22.22 & 77.78 \\
\hline
\end{tabular}

Disease control studies: Small sized nursery beds of $1 \mathrm{~m}^{2}$ were made in green house from field soil. There were 18 treatments each with 3 replications laid out in a randomized block design. All the nursery beds except in two treatments were inoculated with $P$. aphanidermatum multiplied on sand-maize meal medium @ $500 \mathrm{~g} / \mathrm{m}^{2}$. After three days of stabilization of the pathogen, the beds in 27 treatments were drenched with 10\% MPG @ 3 litres $/ \mathrm{rn}^{2}$. In four different treatments, the powdered neem cake@250 g/ $\mathrm{m}^{2}$ and 10\% fresh neem leaf extract @ $31 / \mathrm{rn}^{2}$ were added to nursery beds amended and unamended with MPG. In rest of the treatments, various antagonists viz., T. viride-I, $T$. harzianum-II, T. virens, B. subtilis and P. fluorescens were applied to soil @250 $\mathrm{g} / \mathrm{m}^{2}$. After 3 days of application of antagonists and various amendments, 5 furrows were made in each bed, and in each furrow 15 tomato seeds were sown. Observations on pre-emergence and post- emergence damping - off were taken 10 and 30 days after sowing. Percent seedling mortality and disease control were calculated on the basis of seedling stand in uninoculated and inoculated control, respectively.

Table 2. Effect of Maha Pancha Gavya (MPG) on the growth of bacterial antagonists of Pythium aphanidermatum in cultre.

\begin{tabular}{rllll}
\hline Treatment & Concentration (\%) & & B. subtilis & P. fluorescens \\
\hline \multirow{4}{*}{ MPG } & 0 & +++ & +++ \\
& 5.0 & +++ & ++++ \\
& 10.0 & +++ & +++ \\
& 25.0 & +++ & +++ \\
\hline
\end{tabular}

$++=$ Moderate growth

$+++=$ Profuse growth

$++++=$ Highly profuse growth 


\section{Results and Discussion}

MPG was moderately effective in inhibiting the mycelial growth of $P$. aphanidermatum in vitro (Table 1). It inhibited the pathogen's growth by $5.56 \%$ at the lowest concentration i.e., $5 \%$ after 2 days of incubation. Mycelial growth at 25 and 50\% concentrations was nil upto 2 days of incubation and it was only after 2 days that some membranous type of growth appeared on the surface of the medium. Sugha (2005) also found MPG to be highly toxic to 5 soil borne pathogens i.e., Rhizoctonia solani, Scierotium rolfsii, Fusarium solani, Scierotinia scierotiorum, Phytophthora colocasiae in vitro and very effective in controlling damping-off of cauliflower seedlings in nursery bed. In the present studies, the radial growth of various isolates of Trichoderma spp. was affected even at the lowest concentration of MPG, but it was fluffy and sporulated profusely. $T$ viride-IV exhibited maximum inhibition at 50\% concentration of MPG.

Table 3. Effect of Maha Pancha Gavya (MPG) in integration with antagonists and neem products in controlling damping off of tomato caused by Pyihium aphanidermatum.

\begin{tabular}{|c|c|c|c|c|c|}
\hline Treatments & $\begin{array}{c}\text { Seedling } \\
\text { stand }\end{array}$ & $\begin{array}{c}\text { Seedling } \\
\text { mortality } \\
(\%)\end{array}$ & $\begin{array}{c}\text { Disease } \\
\text { control } \\
(\%)\end{array}$ & $\begin{array}{c}\text { Seedling } \\
\text { height } \\
(\mathrm{cm})\end{array}$ & $\begin{array}{l}\text { Increase in } \\
\text { height over } \\
\text { control (\%) }\end{array}$ \\
\hline T.viride-I & 44.00 & 29.03 & 37.93 & 28.60 & 9.16 \\
\hline T. viride-I+MPG & 49.00 & 20.96 & 55.18 & 32.61 & 24.42 \\
\hline T. harzianum-II & 43.33 & 30.64 & 34.48 & 26.60 & 1.52 \\
\hline T. harzianum-II+MPG & 48.00 & 22.58 & 51.72 & 29.02 & 10.68 \\
\hline T. virens & 42.33 & 32.25 & 31.04 & 29.42 & 12.21 \\
\hline T.virens+MPG & 47.00 & 24.19 & 48.27 & 30.21 & 15.26 \\
\hline B. subtilis & 46.00 & 25.80 & 44.83 & 27.10 & 3.43 \\
\hline B. subtilis $+M P G$ & 52.00 & 16.12 & 65.33 & 33.10 & 26.33 \\
\hline P.fluorescens & 43.33 & 30.64 & 34.48 & 27.51 & 4.96 \\
\hline P.fluorescens+ MPG & 49.00 & 20.96 & 55.18 & 31.21 & 17.93 \\
\hline Neemcake & 41.33 & 33.87 & 27.58 & 29.20 & 11.45 \\
\hline MPG+Neem Cake & 62.00 & 0.00 & 100.00 & 33.30 & 27.09 \\
\hline Neem leaf extract & 37.00 & 40.32 & 13.79 & 28.01 & 6.87 \\
\hline MPG + Neem leaf extract & 6300 & 000 & 10000 & 3280 & 2519 \\
\hline Control -l (Inoculated) & 33.00 & 46.77 & - & 24.50 & - \\
\hline Control -I (Inoculated +MPG) & 47.00 & 24.19 & 48.27 & 29.00 & 10.68 \\
\hline Contro-III (Uninoculated) & 6200 & - & - & 26.21 & - \\
\hline Contro-III (Uninoculated +MPG) & 5800 & - & - & 30.40 & 16.03 \\
\hline C.D.(P0.05) & & 181 & & 1.12 & \\
\hline
\end{tabular}

- Neem cake added @ 250g1 $\mathrm{m}^{2}$ of nursery bed

- Neem leaf extract (10\%) was applied @ 31/ $\mathrm{rn}^{2}$ of nursery beds

- MPG (10\%) applied @ 31/ $\mathrm{rn}^{2}$ of nursery bed

- Antagonists applied @ 250g/ $\mathrm{m}^{2}$ of nursery bed 
MPG was not toxic against bacterial antagonists. At the lowest concentration, maximum growth of $P$. fluorescens was observed (Table 2). At the highest concentration of MPG, the growth of $B$. subtilis and $P$. fluorescens was decreased.

Soil application of MPG in nursery beds improved seedling stand and decreased percent seedling mortality in inoculated soil. Disease control given by MPG was better than that obtained with individual antagonist (Table 3). In integration with antagonists, the disease control was significantly increased in all the treatments. Among the various integrated treatments, B. subtilis + MPG treatment gave maximum disease control (65.33\%). When MPG was used in integration with neem cake and neem extract, $100 \%$ disease control was achieved. This may be due to the additive effect of both the neem products and the MPG on the multiplication of antagonists. Many workers have reported that organic amendments stimulate antagonistic microorganisms in soil (Arjunan et al., 1987; Rao and Sitaramaiah, 2000; Champawat and Sharma, 2003). MPG also enhanced seedling length more so in the presence of antagonists (Table 3). The increase in seedling length was probably due to the presence of hormones in MPG (Padmodaya, 1994). It was maximum when MPG was applied in integration with neem products. Although there is no information available on the efficacy of MPG in controlling damping-off tomato by Pythium spp. Reddy and Padmodaya (1996) found it to be highly effective both alone and in integration with neem cake and T. viride against Fusarium wilt of tomato. Further, they reported that it increased the vigour as well as the yield in tomato. Jahagirdhar et al. (2000) reported it to be effective in suppressing panama disease of banana caused by $F$. oxysporum f. sp. cubense. Thus, the present results revealed the antifungal potential of MPG and it can be one of the major components in the management of plant diseases, especially soil borne one's in "Organic Agriculture”.

\section{References}

Arjunan, G., T. K. Kandeswamy and R. Jayarajan. 1987. Biological Control of Plant Diseases. A workshop, Department of Plant Pathology, Tamilnadu Agricultural University, Coimbatore, p. 34 (Abstr.)

Austen, R. A. 1657. A Treatise of fruit trees. Henery Hall, Oxford.

Champawat, R. S. and R. S. Sharma. 2003. Integrated management of nursery diseases in Brinjal, Chilli and Onion. J. Mycol. Pl. Pathol. 33: 290-291.

Grover, R. K. and J. D. Moore. 1962. Toximetric studies of fungicides against brown rot organisms Sclerotinia fructicola and Scierotinia laxa. Phytopathology 52: 876- 880.

Jahagirdar, Shamarao; A. L., Siddaramaiah and G. R. Ramaswamy. 2001. Influence of biocontrol agents and MPG-3 on Fusarium oxysporum f. sp. cubense, incitant of Panama disease of banana. Pt. Dis. Res. 16: 68-72. 
Neelamegam, R. and T. Govindarajalu. 2002. Integrated application of Trichoderma viride and farm yard manure to control damping off of tomato. J. Biol. Control 16: 65-69.

Padmodaya, B. 1994. Biological control of seedling disease and wilt of tomato (Lycopersicon esculenum (Mil1.) caused by Fusarium oxysporum f. sp. lycopersici. Ph.D. Thesis, UAS, Bangalore, 169 pp.

Purushothaman, S., V. Kurucheve and J. Deepa. 2003. Antifungal activity of animal excreta against damping off of Pythium aphanidermatum. Indian Phytopath. 56: 320-321.

Raja, J. and V. Kurcheve. 1998. Influence of plant extracts and buffalo urine on the growth and sclerotial germination of Macrophomina phaseolina. indian Phytopath.. 51: 102-103.

Raja, J. and V. Kurcheve. 1999. Fungicidal activity of buffalo (Babulus bubalis) urine : A new record. Madras Agric. J. 86: 614-616.

Rao, S. K. T. and K. Sitaramaiah. 2000. Stimulation of Trichoderma spp. and inhibition of Aspergillus niger in water extracts of neem cake amended soil in vitro. J Mycol. P1. Pathol. 30: 236-238.

Reddy. H., Rarnachandra and B. Padmodaya. 1996. Borne remedy. Down to Earth 5(9): 54.

Sugha, S. K. 2005. Antifungal potential of Panchagavya. P1. Dis. Res. 20: 156-158. 